\title{
The HOME FAST BRAZIL self-report version: translation and transcultural adaptation into Brazilian Portuguese
}

\author{
Jarbas Melo Filho ${ }^{*^{*}}$ (D), Natacha Verônica Bazanella ${ }^{2}$, Audrin Said Vojciechowski ${ }^{3}$, Elisiê Rossi Ribeiro Costa ${ }^{2}$, \\ Lynette Mackenzie $^{4}$ and Anna Raquel Silveira Gomes 3,5
}

\begin{abstract}
Objective: To translate and cross-culturally adapt the Home Falls and Accidents Screening Tool Self-report into Brazilian Portuguese and to correlate with the history of falls.

Methods: The translation and transcultural adaptation process followed international parameters. The Home Falls and Accidents Screening Tool Brazil Self-report, the Mini-Mental State Examination and the history of falls were applied to 10 elderly in the pre-test and to 41 in the final. Demographic and anthropometric data were also evaluated. Spearman correlation coefficient was performed.

Results: The participants considered the questionnaire easy to understand and did not report any doubts to answer the final version. There was significant correlation between: Home Falls and Accidents Screening Tool Brazil Self-report score and number of falls $(\rho=0.31, p=0.02)$ and the lighting and bathroom domains with presence of falls at home ( $\rho=0.44, p=0.00$ and $\rho=0.33, p=0.02$, respectively). The questionnaire indicated fall's risk scoring, $10( \pm 2)$.

Conclusion: The Home Falls and Accidents Screening Tool Brazil Self-report showed to be comprehensible and feasible tool for self-assessment of domiciliary falls risk in Brazilian older people. The scores indicated fall's risk and were associated with the history of falls.
\end{abstract}

Keywords: Aged, Accidental falls, Environmental hazards, Housing

\section{Introduction}

One of the main health risks for people aged over 65 is falling which can lead to injuries of joints, muscles, fractures and traumatic brain injuries $[1,2]$. The aetiology of falling is multifactorial, including intrinsic factors such as strength, gait, balance, cognitive, psychological and extrinsic factors related to social and environmental conditions $[2,3]$. The risk of falls increases according to the number of factors and the age [3]. To target falls prevention, screening tools are needed to be able to identify older people at risk of falling.

\footnotetext{
* Correspondence: jarbasmf@hotmail.com

${ }^{1}$ Massage course Federal Institute of Parana, Rua Doutor Constante Coelho,

567, Jardim das Américas, Curitiba, Paraná CEP: 81530470, Brazil

Full list of author information is available at the end of the article
}

Indoor falls are generally associated with worse health conditions and involve not only environmental hazards but also intrinsic factors, such as behaviour, functionality, balance and perception of the older in face to the risks [2, 4]. Authors [5] reported these risks by pointing out that extrinsic factors such as stairs, mats, and loose flooring were more present in the residences of older people prone to falls in comparison to the homes of those were not. In addition, a study in the city of São Paulo showed that out of $29 \%$ of older people who fell in the previous 12 months, $59 \%$ fell indoors [4].

Early screening has been recommended for falls risk detection. However, easy-to-administer and costeffective assessment tools are necessary for selfscreening [1, 6]. Despite the existence of falls risk

(c) The Author(s). 2020 Open Access This article is licensed under a Creative Commons Attribution 4.0 International License, which permits use, sharing, adaptation, distribution and reproduction in any medium or format, as long as you give appropriate credit to the original author(s) and the source, provide a link to the Creative Commons licence, and indicate if changes were made. The images or other third party material in this article are included in the article's Creative Commons licence, unless indicated otherwise in a credit line to the material. If material is not included in the article's Creative Commons licence and your intended use is not permitted by statutory regulation or exceeds the permitted use, you will need to obtain permission directly from the copyright holder. To view a copy of this licence, visit http://creativecommons.org/licenses/by/4.0/. 
screening tools described in the international literature, choosing a tool that is capable of assessing different profiles of older people from distinct home settings can be complex [7-10]. Moreover, the tools are not incorporated into the daily routines of health professionals due to various reasons, such as lack of translated and validated instruments, time to apply tools and lack of self-report versions which are simple to analyse and to identify a clinical risk score $[8,9]$.

Studies in Brazil have used checklists to identify hazards related to fall risk for older people in their homes, such as the presence of stairs and ramps without anti slip strip and grab bars, low toilet seats, pets and objects on the floor $[5,11]$. These studies used instruments translated into Portuguese for risk assessment of home falls, but the process of cross-cultural adaptation for Brazilian Portuguese was not carried out.

Similarly, authors [12] developed a tool named the Home Falls and Accidents Screening Tool (HOME FAST) to assess the risk of falls in the homes of older people by means of a visit from a health professional. However, in order to optimize the application of HOME FAST, the authors created a new, self-report version, called Home Falls and Accidents Screening Tool Self-report version (HOME FAST-SR), allowing the assessment of risk of falls without needing a visit from a health professional at the older person's residence [13]. Due to it being a selfreport version, this instrument substantially diminishes the time needed for an assessment. Thus, the aim of the present study was to perform the translation and transcultural adaptation of the HOME FAST-SR into Brazilian Portuguese and to correlate with the history of falls.

\section{Methods}

\section{Study design}

Cross-sectional study.

\section{Study population and selection criteria}

The study population was community-dwelling older people.

The inclusion criteria were community-dwelling older people of both sexes, who attended a physiotherapist consultation scheduled at the Basic Health Units of the city of Curitiba between June and August 2017. Participants were invited to take part in the study verbally by a physiotherapist at the Basic Health Units while they were waiting for consultations or during it. Those who agreed to complete the questionnaires related to this research signed a Free and Informed Consent Form. Individuals who scored less than 18/19 (for participants with no formal education) and less than 24/25 (with formal education) on the Mini-Mental State Examination (MMSE) were excluded for possible cognitive impairment [14]. One physiotherapist enrolled and interviewed all the participants at the Basic Health Units.

\section{Data collection}

The translation and transcultural adaptation of the HOME FAST-SR followed the steps: 1) translation; 2) synthesis; 3) back-translation; 4) specialist committee: proofreading and pre-final version; 5) pre-test; 6) analysis by the specialist committee and the final version of the instrument [15].

The HOME FAST-SR questionnaire comprises 7 domains (floors, furniture, lighting, bathroom, storage, stairways/steps and mobility), divided into 20 questions subdivided into 97 items with answers "yes" and "no" [13]. In order to calculate the score to estimate the risk of fall, it was necessary a conversion table, based on the score of the original HOME FAST, which presents a total score of 25 . The higher the score the greater the fall risk of older persons at home environment. The cut-off point equal to or greater than 8 indicate a risk of falls [12].

The translation of the questionnaire was performed by two English as a Second Language teachers who were native speakers of Brazilian Portuguese and fluent in English; one of them was a health professional (a physiotherapist) and was aware of the concepts examined in the questionnaire, whereas the other was a social communication graduate. Two versions translated of the questionnaire were created and then analysed and compared by a committee (translators and researchers involved in the study) in order to synthesize the Brazilian Portuguese version. Then, this version was translated into English (back translation) by two translators who were native speakers of English and fluent in Portuguese, were not familiar with the original version and did not have knowledge about health, thus creating new English versions of the questionnaire [15].

The two back-translations of the HOME FAST-SR were then reviewed by a multidisciplinary specialist committee including four physiotherapists and an occupational therapist, resulting in the pre-final version of the Home Falls and Accidents Screening Tool Brazil Self-report (HOME FAST BRAZIL-SR). The pre-final version was applied in 10 participants as an interview [15]. In addition, the pre-final version of the questionnaire was considered adequate when more than $80 \%$ of the sample comprehended the questionnaire [16].

The final version of transcultural adaptation was carried out considering a sample size between 30 to 40 individuals [15].

Demographic information including age, gender and education level (years of formal education) were collected by self-report, as well as history of falls, by asking if the participants had at least one fall in the past 12 
months. If so, they were asked about frequency and place of occurrence $[17,18]$. In addition, the participants' body mass and height were measured using a Balmak $^{\circ}$ mechanic anthropometric scale. Their Body Mass Index (BMI) was classified considering the following thresholds: underweight $\left(\mathrm{BMI}<23 \mathrm{~kg} / \mathrm{m}^{2}\right)$, normal $(23<$ $\left.\mathrm{BMI}<28 \mathrm{~kg} / \mathrm{m}^{2}\right)$, overweight $\left(28<\mathrm{BMI}<30 \mathrm{~kg} / \mathrm{m}^{2}\right)$, obesity $\left(\mathrm{BMI}>30 \mathrm{~kg} / \mathrm{m}^{2}\right)[19]$.

\section{Statistical analysis}

The Statistical Package for the Social Sciences (SPSS) software, version 21.0, was used to perform the statistical analysis. Nominal and/or ordinal variables were described in terms of absolute and relative frequency, whereas numeric variables were described according to mean and standard deviation.

In order to assess the correlation between total score of the HOME FAST BRAZIL-SR and its domains (floors, furniture, lighting, bathroom, storage, stairways/steps, mobility) with the history of falls (presence, frequency and place of occurrence), the Spearman Correlation Coefficient was used for non-parametric data. Hopkins scale of magnitudes [20]. was used to interpret correlation coefficients, as follows: trivial $(<0.1)$; small (between 0.1-0.29); moderate (0.30-0.49); large (0.50-0.69); very large $(0.70-0.90)$; almost perfect $(>0.90)$. Significance level was set at $p \leq 0.05$.

\section{Ethical aspects}

This study was approved by the Research Ethics Committee of the Pequeno Príncipe College, Curitiba, Paraná, Brazil (number 1.960.069/2017), and by the Research Ethics Committee of the Health Department of the City of Curitiba, Curitiba, Paraná, Brazil (number 2.083.841/ 2017), in accordance with Resolution number $466 / 2012$ of the National Health Council.

Authorization from the HOME FAST-SR authors was obtained to translate the questionnaire.

\section{Results}

The mean age of participants was $72( \pm 5)$ years old and they were mostly female (87.8\%). The majority of participants were classified as obese (49\%). The mean score of the MMSE was $27( \pm 2)$ and the average years of formal education were $6( \pm 4)$. Moreover, $54 \%$ reported falls in the last year ( $29 \%$ one fall, $10 \%$ two falls, $10 \%$ three falls and $5 \%$ four or more falls), $36 \%$ of these were falls at home, as shown Table 1.

Seven older people were excluded from the study due to achieving a score below 24 points at the MMSE, despite had declared formal education, and eight older people refused to answer the questionnaire due to lack of time during the physiotherapist consultation, representing 14\% rejection. Therefore, from the initial sample
Table 1 Demographic and anthropometric characteristics and history of falls of participants $(n=41)$, Curitiba, PR, Brazil, 2017

\begin{tabular}{|c|c|c|}
\hline Characteristics & Mean \pm SD & n (\%) \\
\hline Age (years) & $72 \pm 5$ & \\
\hline \multicolumn{3}{|l|}{ Sex } \\
\hline Female & & $36(88)$ \\
\hline Male & & $5(12)$ \\
\hline Body Mass (kg) & $73 \pm 15$ & \\
\hline Height (cm) & $159 \pm 0.07$ & \\
\hline BMI $\left(\mathrm{Kg} / \mathrm{m}^{2}\right)$ & $29 \pm 6$ & \\
\hline Underweight & & $7(17)$ \\
\hline Normal & & $9(22)$ \\
\hline Overweight & & $5(12)$ \\
\hline Obesity & & $20(49)$ \\
\hline MMSE (score) & $27 \pm 2$ & \\
\hline Formal Education (years) & $6 \pm 4$ & \\
\hline \multicolumn{3}{|l|}{ History of falls } \\
\hline Presence of falls in the last year & & $22(54)$ \\
\hline Occurrence of falls at home & & $15(36)$ \\
\hline \multicolumn{3}{|l|}{ Frequency of falls } \\
\hline One fall & & $12(29)$ \\
\hline Two falls & & $4(10)$ \\
\hline Three falls & & $4(10)$ \\
\hline For and more falls & & $2(5)$ \\
\hline
\end{tabular}

$S D$ standard deviation, $K g$ kilograms, $\mathrm{cm}$ centimeters, $\mathrm{Kg} / \mathrm{m} 2$ kilogram $/$ meter2, $B M I$ body mass index, MMSE mini-mental state examination, $n$ number, $\%$, percentage

of 56 older people, 41 were included for the data analysis.

During the translation process into Brazilian Portuguese, the two forward translations presented some differences. The committee reached a consensus for determining different choices of words, without changing the meaning of the sentence. The same happened in the back-translation from Brazilian Portuguese into English.

The pre-final version of the HOME FAST BRAZIL-SR was applied to 10 older people as an interview. Each question was followed by the item "did you understand this question?". Some changes were performed and a new application was necessary because around $80 \%(n=8)$ of interviewees did not understand some items from the questionnaire. The questions were reviewed by the multidisciplinary specialist committee and adapted as semantic and cultural equivalents, resulting in the final version, which was then applied to 41 older people, thus finalizing the translation and transcultural adaptation process. The changes into the final version are described in Table 2.

Moreover, the question 16C, "Você precisa se afastar para trás e descer degraus na entrada ao abrir a tela (se houver) ou a porta?" (Do you need to step back and go 
Table 2 Changes Performed After Pre-Final Version Application, Curitiba, PR, Brazil, 2017

\begin{tabular}{|c|c|c|}
\hline Questions & Translation into Brazilian Portuguese & Final Version for Brazilian Portuguese \\
\hline \multirow{2}{*}{$\begin{array}{l}10 \mathrm{~h} \text { : Is there a long walk between the } \\
\text { toilet and your bedroom? }\end{array}$} & T1: A distância entre o banheiro e seu quarto é longa? & \multirow{2}{*}{$\begin{array}{l}\text { A distância entre o banheiro e seu quarto é } \\
\text { longa (mais de duas portas de distância)? }\end{array}$} \\
\hline & T2: A distância entre o banheiro e seu quarto é longa? & \\
\hline \multirow[t]{2}{*}{$\begin{array}{l}\text { 14a: Can you reach items in the kitchen } \\
\text { without bending? }\end{array}$} & $\begin{array}{l}\text { T1: Você consegue alcançar os utensílios da sua } \\
\text { cozinha sem se curvar/ inclinar o corpo? }\end{array}$ & \multirow[t]{2}{*}{$\begin{array}{l}\text { Geralmente você consegue alcançar utensílios } \\
\text { na cozinha sem precisar se curvar? }\end{array}$} \\
\hline & $\begin{array}{l}\text { T2: Você consegue alcançar itens na cozinha sem } \\
\text { precisar se curvar? }\end{array}$ & \\
\hline \multirow{2}{*}{$\begin{array}{l}\text { 14b: Can you reach items in the kitchen } \\
\text { without climbing or standing on } \\
\text { something? }\end{array}$} & $\begin{array}{l}\text { T1: Você consegue alcançar os utensílios da sua } \\
\text { cozinha sem ter que subir em algo? }\end{array}$ & \multirow[t]{2}{*}{$\begin{array}{l}\text { Geralmente você consegue alcançar utensílios } \\
\text { na cozinha sem precisar subir em algo? }\end{array}$} \\
\hline & $\begin{array}{l}\text { T2: Você consegue alcançar itens na cozinha sem } \\
\text { precisar subir em algo? }\end{array}$ & \\
\hline \multirow{2}{*}{$\begin{array}{l}\text { 16c: Can you open your screen door } \\
\text { without stepping backwards down any } \\
\text { entrance steps? }\end{array}$} & $\begin{array}{l}\text { T1: Você consegue abrir a porta/ tela sem ter que } \\
\text { descer degraus na porta de entrada? }\end{array}$ & \multirow{2}{*}{$\begin{array}{l}\text { Você precisa se afastar para trás e descer } \\
\text { degraus na entrada ao abrir a tela (se houver) } \\
\text { ou a porta? }\end{array}$} \\
\hline & $\begin{array}{l}\text { T2: Você consegue abrir a tela da porta (se houver) } \\
\text { sem precisar se afastar para trás, descendo degraus na } \\
\text { entrada? }\end{array}$ & \\
\hline
\end{tabular}

T1: Brazilian Portuguese version by the first forward translator;

T2: Brazilian Portuguese version by the second forward translator

down entrance steps in order to open your screen (if there is one) or door?), was changed in regards to scoring. Whereas in the original HOME FAST-SR this question scores if the answer is "no", due to the modification in meaning for better understanding by the population, the question scores was changed for "yes" in the adaptation process.

There was a moderate association between the total HOME FAST BRAZIL-SR score and number of falls ( $\rho=0.319, p=0.021)$, small association between the stairways/steps domain and presence of falls $(\rho=0.252$, $p=0.056)$, small association between the bathroom domain and number of falls $(\rho=0.255, p=0.054)$ and moderate association between the lighting and the bathroom domains with presence of falls at home $(\rho=0.448$, $p=0.002$ and $\rho=0.333, p=0.020$, respectively). Other correlations can be seen in the Table 3 .

In relation to the screening of falls risk score in the questionnaire HOME FAST BRAZIL-SR, the mean score of the participants was $10( \pm 2)$, indicating a risk of falls in the home environment.
In order to achieve a score in the HOME FAST BRASIL-SR questionnaire, it was necessary to convert the 97 items into 25 of the HOME FAST questionnaire. Thus, a new table was developed to support the conversion of the HOME FAST BRAZIL-SR to the equivalent HOME FAST score (Table 4). The conversion process identified some divergences between the original HOME FAST items and the corresponding items from the HOME FAST BRAZIL-SR. In order to clarify this, the author of the HOME FAST and HOME FAST-SR was contacted and approved some adjustments to the HOME FAST BRAZIL-SR.

\section{Discussion}

The version of the HOME FAST-SR was translated and adapted transculturally into Brazilian Portuguese, the HOME FAST BRAZIL-SR, being considered a useful instrument for self-report assessment of home falls risk in older Brazilians.

The translation, synthesis and back translation steps of the HOME FAST BRAZIL-SR were straightforward

Table 3 Spearman Correlation between HOME FAST BRAZIL-SR and your domains with history of falls, Curitiba, PR, Brazil, 2017

\begin{tabular}{llll}
\hline & Falls (yes or no) & Number of falls & $\begin{array}{l}\text { Falls at home } \\
\text { (yes or no) }\end{array}$ \\
\hline HOME FAST BRAZIL-SR total score & 0.220 & $0.319^{*}$ & -0.002 \\
Floors domain & -0.208 & 0.148 & -0.110 \\
Furniture domain & 0.078 & 0.054 & -0.022 \\
Lighting domain & -0.116 & -0.073 & $0.448^{*}$ \\
Bathroom domain & 0.074 & $0.255^{*}$ & $0.333^{*}$ \\
Storage domain & 0.133 & 0.140 & 0.059 \\
Stairways/steps domain & $0.252^{*}$ & 0.203 & 0.207 \\
Mobility domain & 0.183 & 0.157 & -0.142 \\
\hline
\end{tabular}

${ }^{*} p \leq 0.05$ 
Table 4 HOME FAST BRAZIL-SR Score Conversion with the corresponding score of the 25 HOME FAST items, Curitiba, PR, Brazil,

\begin{tabular}{|c|c|c|}
\hline HOME FAST Item & HOME FAST BRAZIL-SR Item & Conversion \\
\hline 17 & 1,14 & Scores if "yes" for 1 or "no" for $14 \mathrm{C}$ or $14 \mathrm{D}$ or $14 \mathrm{E}$ \\
\hline 4 & 2 & Scores if "no" for $2 \mathrm{~A}$ or $2 \mathrm{~B}$ \\
\hline 2 & 3 & Scores if "no" for $3 \mathrm{~A}$ \\
\hline 3 & 4 & Scores if "yes" for $4 A$ or $4 B$ or $4 C$ \\
\hline 1 & 5 & Scores if "yes" for $5 A$ or $5 B$ or $5 C$ or $5 D$ or $5 E$ \\
\hline 7 & 6,7 & Scores if "no" for $6 \mathrm{~A}$ or "yes" for $6 \mathrm{~B}$ or if yes for $7 \mathrm{G}$ \\
\hline 8 & 7 & Scores if "no" for 7A, 7B, 7C - all of them \\
\hline 9 & 7 & Scores if "no" for $7 \mathrm{D}$ or $7 \mathrm{E}$ or "yes" for $7 F$ \\
\hline 6 & 8 & Scores if "yes" for $8 \mathrm{~A}$ or $8 \mathrm{~B}$ or "no" for $8 \mathrm{C}$ \\
\hline 5 & 9 & Scores if "yes" for $9 \mathrm{C}$ or if "no" for $9 A$ or $9 B$ or $9 D$ \\
\hline 10 & 10 & Scores if "no" for $10 \mathrm{~A}$ or $10 \mathrm{C}$ or $10 \mathrm{E}$ or "yes" for $10 \mathrm{~B}$ or $10 \mathrm{D}$ \\
\hline 15 & 10 & Scores if "no" for $10 \mathrm{~F}$ or "yes" for $10 \mathrm{G}$ or $10 \mathrm{H}$ \\
\hline 11 & 11,12 & Scores if "no" for $11 \mathrm{~A}$ or $11 \mathrm{~B}$ or $12 \mathrm{~B}$ or "yes" for $12 \mathrm{~A}$ or $12 \mathrm{C}$ \\
\hline 13 & $11,12,13$ & Scores if "no" for $11 \mathrm{D}$ or $11 \mathrm{E}$ or $12 \mathrm{D}$ or $13 \mathrm{C}$ \\
\hline 14 & $11,12,13$ & Scores if "no" for $11 \mathrm{C}$ or $12 \mathrm{E}$ or $13 \mathrm{D}$ \\
\hline 12 & 13 & Scores if "no" for 13A or "yes" for 13B \\
\hline 16 & 14 & Scores if "no" for $14 A$ or $14 B$ \\
\hline 20 & 15 & Scores if "yes" for $15 \mathrm{~A}$ or $15 \mathrm{~B}$ or $15 \mathrm{C}$ or $15 \mathrm{D}$ or $15 \mathrm{E}$ \\
\hline 21 & 15 & Scores if "no" for $15 \mathrm{~F}$ or $15 \mathrm{H}$ or "yes" for $15 \mathrm{G}$ \\
\hline 18 & $15 a$ & Scores if "yes" for $15 \mathrm{~A}^{\mathrm{a}}$ or "no" for $15 \mathrm{I}$ or $15 \mathrm{~J}$ or $15 \mathrm{~K}$ \\
\hline 19 & $15 b$ & Scores if "yes" for $15 B^{b}$ or "no" for $15 \mathrm{~L}$ or $15 \mathrm{M}$ or $15 \mathrm{~N}$ \\
\hline 22 & 16 & Scores if "no" for $16 \mathrm{~A}$ or $16 \mathrm{~B}$ or "yes" for $16 \mathrm{C}$ \\
\hline 23 & 17 & Scores if "yes" for $17 \mathrm{~A}$ or $17 \mathrm{~B}$ or $17 \mathrm{C}$ or $17 \mathrm{D}$ or $17 \mathrm{E}$ or $17 \mathrm{~F}$ \\
\hline 24 & 18,19 & Scores if "yes" for 18 or "no" for $19 \mathrm{~A}$ or $19 \mathrm{~B}$ or $19 \mathrm{C}$ \\
\hline 25 & 20 & Scores if "yes" for $20 \mathrm{~A}$ or $20 \mathrm{~B}$ or $20 \mathrm{C}$ \\
\hline
\end{tabular}

$15 \mathrm{~A}^{\mathrm{a}}, 15 \mathrm{~B}{ }^{\mathrm{b}}$ refer to the questions themselves, not to the subdivision of question 15 . SR, self-report

since there were no many differences between translated terms. The questions showing more than $20 \%$ misunderstanding were grammatically adequate phrasing for Brazilian Portuguese and had cultural equivalence to the Brazilian older population. Authors [15] state that equivalence between expressions based on the original version should be sought, although colloquial expressions of a specific language might also be considered and items ought to capture the daily life experience of the relevant culture. Therefore, some examples were added at the end of some questions, such as question 1: "Você usa algum tipo de equipamento auxiliar para caminhar em casa (bengala e andador)?" (Do you use a walking aid to walk around the home (cane or walker)?), question 2A: "A parte debaixo de todos os tapetes é antiderrapante (não escorrega)?" (Are the bottom part of all the mats slip resistant (do not slip)?), question 6B: "Os corredores ou pisos da sua casa ficam mal iluminados (sombras)?" (Are the hallways or floors of your home badly lit (shadows)?), question 7G: "Durante o dia tem locais na sua casa que fazem reflexo (brilho forte)?" (During the day, do you have places in your house that reflect light (strong glow)?), question 14C: "Você faz as refeições (alimenta-se) na cozinha?" (Do you have your meals (eat) in the kitchen?), question 17F: "Tem objetos sobre as calçadas (por exemplo, mangueiras)?" (Are there any objects over your paths (for example, hoses)?), question 19C: "Seus calçados têm solado antiderrapante (que não escorrega)?" (Do your shoes have non-slip soles (that do not slip)?)

We determined that for the final score of the HOME FAST BRAZIL-SR, the cut off score for falls risk should be 8 out of 25, the same as the original HOME FAST. In order to obtain the final score, it was necessary to convert the 97 questions of the HOME FAST BRAZIL-SR for the 25 questions of HOME FAST questionnaire [12, 13, 21].

The HOME FAST-SR enables saving time and travel for health professionals. Most health professionals have high workloads thus limiting the time for home visits, 
which would provide a more technical and detailed assessment. Nevertheless, this tool does demand some time, 10-15 $\mathrm{min}$, for the older person to complete due to the number of questions to be answered, and more 10 min for the health professional to convert the score. Even so, the HOME FAST-SR version is an important tool to guide health professionals to recommend home adaptations to prevent falls. Also, depending on the fall risk detected by the questionnaire score, the health professionals can decide if a home visit is necessary.

We do however highlight the importance of the HOME FAST, used by a health professionals during a home visit in order to determine changes, prevent, and diminish falls risk inside the home [12, 13]. This tool is currently also being translated into Brazilian Portuguese and will evaluate the psychometric properties.

The average HOME FAST BRAZIL-SR score [13] derived from the HOME FAST questionnaire indicates falls risk considering the cut off equal or higher to 8 , observed in $95 \%$ of the sample assessed in the current study [21]. This is in line with the study that created the Home Falls and Accidents Screening Tool (HOME FAST) Self-report version, which reported a mean score of 9.39 for 568 community-dwelling older women in Australia [13].

Participants presented as having fall risk according to the HOME FAST-SR score as well as they reported falls at home (36\%). This indicates the need for assessment regarding the risk of falls in the older adults.

In relation to the HOME FAST BRAZIL-SR domains, in the present study, the stairs were related to falls, which may suggest that poorly designed stairs, including those without supports, handrails or non-slip indicate a high risk of falls. This is consistent with findings that $75 \%$ of falls occur when older people are descending the stairs [22].

Furthermore, the bathroom domain was associated with both the presence of falls at home and the number of falls. A study that evaluated the prevalence of falls in the house of aged people showed that most falls occurred in the bathroom (26.2\%) [23]. Another study, but assessing institutionalized older people, also found the bathroom was the main location for falls [24].

There was also a correlation between illumination levels and falls at home. The World Health Organization (WHO) points out that poorly designed stairs or irregular step and environments around the house with slippery floors, are associated with low illumination, and both factors contribute to falls [3].

The HOME FAST BRAZIL-SR reliability is currently being developed, and soon it will contribute to the internal consistency analysis, improving its use as a clinical tool for screening falls risk in the homes of communitydwelling older people.
Some limitations of this study need to be considered. The study sample did not have a gender balance as a larger number of women sought the health service where the study was developed. This was a self-report questionnaire, and memory and cognitive status can contribute to bias when respondents report past falls or what is present in their homes. Thus, for future studies might be suggested to assess cognitive status and the presence of an informant to complement older respondent's answer. The questionnaire is long (97 items) and the answers also need to be converted based on the HOME FAST, which demands time, around $10 \mathrm{~min}$, from the health professional. The HOME FAST-SR tool does not have its own score, and converting its 97 items into 25 possible scores takes time. However, it is ongoing the website for the conversion of HOME FASTSR and also the calculation of final score of both HOME FAST. The HOME FAST-SR original English version has not been translated and adapted transculturally into other languages and countries, therefore, it is impossible to compare the difficulties found in the translation and adaptation process in this study with those of other cultures. The psychometric properties proofing are ongoing.

\section{Conclusion}

The translated and adapted transculturally version into Brazilian Portuguese of the HOME FAST-SR proved to be a feasible tool for self-assessment of domiciliary falls risk in Brazilian older people and it might offer an option to improve the measures of falls prevention for Brazilian older people. The HOME FAST BRAZIL-SR scores indicated fall's risk related to domiciliary factors and were associated with the history of falls, mainly the lighting, bathroom and stairways/steps items. Therefore, HOME FAST BRAZIL-SR can be used by health professionals who assist the older population that speaks Portuguese, to guide prevention strategies to reduce falls at home.

\section{Supplementary information}

Supplementary information accompanies this paper at https://doi.org/10. 1186/s42358-020-00130-y.

\section{Additional file 1.}

\section{Abbreviations}

BMI: Body Mass Index; HOME FAST: Home Falls and Accidents Screening Tool; HOME FAST-SR: Home Falls and Accidents Screening Tool Self-report version; HOME FAST BRAZIL-SR: Home Falls and Accidents Screening Tool Brazil Self-report version; MMSE: Mini-Mental State Examination; SPSS: Statistical Package for the Social Sciences; WHO: World Health Organization

\section{Acknowledgements}

The authors are grateful for older people that took part of this study; The Professor Silvia R. Valderramas from the Department of Prevention and 
Rehabilitation in Physiotherapy at the Federal University of Paraná for the methodological support.

\section{Disclosure statement}

The authors declare they have no potential conflict of interest.

\section{Authors' contributions}

We declare that the authors NVB; JMF and ASV participated the conception, design, analysis and interpretation of data, drafting the article and revising it critically and approval of the version to be published. Also, NVB collected the data. The authors ERRC, LM and ARSG participated the conception and study design, drafting the article and revising it critically and approval of the version to be published. The author(s) read and approved the final manuscript.

\section{Funding}

Residence fellowship from the Brazilian Ministry of Health; Productivity Research fellowship from the National Council for Scientific and Technological Development (CNPq); PhD and Master Fellowships from the Coordenação de Aperfeiçoamento de Pessoal de Nível Superior (CAPES).

\section{Availability of data and materials}

The datasets used and/or analysed during the current study are available from the corresponding author on reasonable request.

\section{Ethics approval and consent to participate}

In accordance with Resolution number 466/2012 of the National Health Council, this study was approved by the Research Ethics Committee of the Pequeno Príncipe College, Curitiba, Paraná, Brazil (number 1.960.069/2017). and by the Research Ethics Committee of the Health Department of the City of Curitiba, Curitiba, Paraná, Brazil (number 2.083.841/2017). The study participants signed a Free and Informed Consent Form.

\section{Consent for publication}

Not applicable.

\section{Competing interests}

The authors declare that they have no competing interests.

\section{Author details}

${ }^{1}$ Massage course Federal Institute of Parana, Rua Doutor Constante Coelho, 567, Jardim das Américas, Curitiba, Paraná CEP: 81530470, Brazil. ${ }^{2}$ Family Health Multiprofessional Residency Program, Curitiba, Parana, Brazil. ${ }^{3}$ Master and PhD Programs in Physical Education, Federal University of Parana, Curitiba, Parana, Brazil. ${ }^{4}$ Occupational Therapy, University of Sydney, Sydney, New South Wales, Australia. ${ }^{5}$ Prevention and Rehabilitation in Physiotherapy Department, Federal University of Parana, Curitiba, Parana, Brazil.

Received: 20 August 2019 Accepted: 30 April 2020

Published online: 19 May 2020

\section{References}

1. Ibrahim A, Singh DKA, Shahar S, Omar MA. Timed up and go test combined with self-rated multifactorial questionnaire on falls risk and sociodemographic factors predicts falls among community-dwelling older adults better than the timed up and go test on its own. J Multidiscip Healthc. 2017;26(10):409-16.

2. World Health Organization (WHO). Integrated care for older people: guidelines on community-level interventions to manage declines in intrinsic capacity. Geneva: World Health Organization; 2017.

3. World Health Organization (WHO). Global report on falls prevention in older age. France: WHO; 2007.

4. Nascimento CF, Duarte YAO, Lebrão ML, Chiavegatto Filho ADP. Individual and contextual characteristics of indoor and outdoor falls in older residents of São Paulom Brazil. Arch Gerontol Geriatr. 2017;68:119-25.

5. Rossetin LL, Rodriques EV, Gallo LH, Macedo DS, Schieferdecker MEM, Pintarelli VL, et al. Indicadores de sarcopenia e sua relação com fatores intrínsecos e extrínsecos às quedas em idosas ativas. Rev Bras Geriatr Gerontol. 2016;19(3):399-414.

6. Pape H-C, Schemmann U, Foerster J, Knobel M. The 'Aachen Falls Prevention Scale' - development of a tool for self-assessment of elderly patients at risk for ground level falls. Patient Saf Surg. 2015;9(7). https://doi. org/10.1186/s13037-014-0055-0. eCollection 2015.

7. Ishimoto Y, Wada T, Kasahara Y, Kimura Y, Fukutomi E, Chen W, et al. Fall risk index predicts functional decline regardless of fall experiences among community-dwelling elderly. Geriatr Gerontol Int. 2012;12(4):659-66.

8. Scott V, Votova K, Scanlan A, Close J. Multifactorial and functional mobility assessment tools for fall risk among older adults in community, homesupport, long-term and acute care settings. Age Ageing. 2007;36(2):130-9.

9. Park SH. Tools for assessing fall risk in the elderly: a systematic review and meta-analysis. Aging Clin Exp Res. 2018;30(1):1-16.

10. Mackenzie L, Byles J. Scoring the home falls and accidents screening tool for health professionals (HOME FAST-HP): evidence from one epidemiological study. Aust Occup Ther J. 2018:65(5):346-53.

11. Ferrer MLP, Perracini MR, Ramos LR. Prevalência de fatores ambientais associados a quedas em idosos residentes na comunidade em São Paulo, SP. Braz J Phys Ther. 2004;8(2):149-54

12. Mackenzie L, Byles J, Higginbotham N. Reliability of the home falls and accidents screening tool (HOME FAST) for identifying older people at increased risk of falls. Disabil Rehabil. 2002;24(5):266-74.

13. Mehraban AH, Mackenzie LA, Byles JE. A self-report home environment screening tool identified older women at risk of falls. J Clin Epidemiol. 2011: 64(2):191-9.

14. Lourenço RA, Veras RP. Mini-Exame do Estado Mental: Características psicométricas em idosos ambulatoriais. Rev Saúde Pública. 2006;40(4):712-9.

15. Beaton DE, Bombardier C, Guillemin F, Ferraz MB. Guidelines for the process of cross-cultural adaptation of self-report measures. Spine (Phila Pa 1976). 2000;25(24):3186-91

16. Nusbaum L, Natour J, Ferraz MB, Goldenberg J. Translation, adaptation and validation of the RolandMorris questionnaire. Braz I Med Biol Res. 2001; 34(2):203-10.

17. Bento PCB, Pereira G, Ugrinowitsch C, Rodacki ALF. Peak torque and rate of torque development in elderly with and without fall history. Clin Biomech. 2010;25(5):450-4.

18. Stevens JA, Mahoney JE, Ehrenreich $\mathrm{H}$. Circumstances and outcomes of falls among high risk community-dwelling older adults. Injury Epidemiology. 2014; $1(5): 1-5$

19. Lebrão ML, Duarte YAO. SABE - Saúde, Bem-estar e Envelhecimento. O Projeto Sabe no município de São Paulo: uma abordagem inicial. Organização Pan-Americana da Saúde: Braślia; 2003.

20. Hopkins WG. Measures of reliability in sports medicine and science. Sports Med. 2000;30(1):1-15.

21. Byles JE, Mackenzie L, Redman S, Parkinson L, Leigh L, Curryer C. Supporting housing and neighbourhoods for healthy ageing: findings from the housing and independent living study (HAIL). Australas J Ageing. 2014:33(1):29-35.

22. Gasparotto LPR, Falsarella GR, Coimbra AMV. As quedas no cenário da velhice: conceitos básicos e atualidades da pesquisa em saúde. Rev Bras Geriatr Gerontol. 2014;17(1):201-9.

23. Galvan SS, Santos CB, Doring M, Portella MR. Prevalence of household falls in long-lived adults and association with extrinsic factors. Rev Latino-Am Enfermagem. 2017;25:e2900.

24. Lojudice DC, Laprega MR, Rodrigues RAP, Rodrigues Júnior AL. Quedas de idosos institucionalizados: ocorrência e fatores associados. Rev Bras Geriatr Gerontol. 2010;13(3):403-12.

\section{Publisher's Note}

Springer Nature remains neutral with regard to jurisdictional claims in published maps and institutional affiliations.

Ready to submit your research? Choose BMC and benefit from:

- fast, convenient online submission

- thorough peer review by experienced researchers in your field

- rapid publication on acceptance

- support for research data, including large and complex data types

- gold Open Access which fosters wider collaboration and increased citations

- maximum visibility for your research: over $100 \mathrm{M}$ website views per year

At $\mathrm{BMC}$, research is always in progress.

Learn more biomedcentral.com/submission 